\title{
Tasa-arvo, perustaidot ja koulutuspolitiikka
}

\author{
Mitä pienempiä ovat aikuisväestön taustaan liittyvät \\ osaamisen erot, sitä osaavampaa on väestö. Suomessa \\ aikuisten osaamisen ja eriarvoisuuden kehitys herättää \\ kysymyksiä PISA-menestyksen ja sen heikkenemisen \\ syistä ja niiden tunnetuista selityksistä.
}

YHDYSVALTOJEN, RANSKAN JA KANADAN kaltaisissa kehittyneissä maissa yli 90 prosentilla aikuisväestöstä oli lukutaito teknisenä taitona jo ensimmäisen maailmansodan jälkeen (Unesco 1953). Osaamistutkimukset, kuten aikuisten kansainvälinen lukutaitotutkimus (International Adult Literacy Study, IALS) 1990-luvulla ja kansainvälinen aikuistutkimus (Programme of International Assessment of Adult Competencies, PIAAC) 2010-luvulla muuttivat käsityksiä lukutaidosta. Ne toivat näkyväksi ja laajemmin globaaliin koulutuspoliittiseen tietoisuuteen sen, että suurella osalla kehittyneidenkin maiden aikuisväestöä on merkittäviä puutteita luetun ymmärtämiseen, tulkitsemiseen ja käyttämiseen tarvittavassa funktionaalisessa lukutaidossa sekä numerotaidossa.

Aikuisten osaamistutkimukset muuttivat myös nuorten osaamisen mittaamista. Programme for International Student Assessment - tutummin PISA - toi
IALS-tutkimuksesta opetussuunnitelmista irrotetun, käytännön elämässä tarvitun osaamisen mittaamisen nuorten osaamistutkimuksiin. Sitä ennen nuorten osaamistutkimukset perustuivat pitkälti opetussuunnitelmapohjaiseen osaamisen arviointiin.

Samalla kun aikuiskoulutustutkimukset tarjoavat ensimmäistä kertaa tietoja aikuisten funktionaalisista perustaidoista, ne tarjoavat uuden tirkistysaukon sekä koulutuspolitiikan mahdollisuuksien että politiikan vaikuttavuuden arviointiin. Ennen aikuisten osaamisen suoraan arviointiin perustuvia survey-aineistoja voitiin aikuisten lopputulemista tarkastella lähinnä muodollista koulutusta sekä työmarkkinatulemia, kuten työllisyyttä, mutta ei esimerkiksi koulutuspoliittisten uudistusten yhteyttä tai vaikutusta osaamiseen.

Kasvatustieteen väitöskirjani teoreettisessa osassa tarkastelen sitä, miten on syytä ymmärtää oppimismahdollisuuksien tasa-arvo, jossa ihminen on 
vastuussa valinnoistaan ja teoistaan muttei olosuhteistaan. Keskeinen kiinnostuksen kohde on mahdollisuuksien tasa-arvon toteutumisen suhde lopputulosten, kuten osaamisen, tasoon. Teoreettinen käsittely pohjustaa empiiristä analyysiä mahdollisuuksien tasaarvon ja oppimistulosten tason välisestä järjestelmätason yhteydestä IALS- ja PIAAC-tutkimusten valossa.

Mahdollisuuksia arvioida koulutuspolitiikan vaikutusta mahdollisuuksien tasa-arvon toteutumiseen eri syntymäkohorteissa rajoittaa se, että aikuisten osaamisaineistot ovat yhä erottelukyvyllään rajallisia. Kun koko työikäisen väestön osaamista mitataan muutaman tuhannen aikuisen otoksella, yksittäistä syntymäkohorttia koskeva otos jää pieneksi. Silti aikuisaineiston analyysi näyttää tuottavan myös tietoa koulutuspolitiikan yhteydestä koulutuksellisen tasaarvon toteutumiseen.

Väitöskirjaani nojautuen tarkastelen esimerkinomaisesti aikuisten osaamistutkimusten antia sille, miten suomalaisen koulutuspolitiikan onnistumista on arvioitu. Tulosten pohjalta kommentoin suomalaisen jatkuvan oppimisen politiikasta käytyä keskustelua.

\section{MAHDOLLISUUKSIEN TASA-ARVO}

Kun ihminen on vastuussa valinnoistaan ja teoistaan, mutta ei niistä olosuhteista, joissa valintoja tekee, vastuu liittyy tiiviisti vapauteen, mahdollisuuteen toimia toisin. ${ }^{1}$ Vapaus valita tyhjenee merkityksestä, jos valinnat eivät millään tavalla vaikuta yksilön lopputulemiin, kuten osaamiseen, varallisuuteen tai hyvinvointiin. Mahdollisuuksien tasa-arvo taas ei toteudu, jos lopputulemat seuraavat valintojen sijaan olosuhteista, joihin yksilö ei ole voinut vaikuttaa.

Mahdollisuuksia ei voida suoraan havaita, koska ne ovat olemassa vain potentiaalina. Käytännössä mahdollisuuksien tasa-arvon empiirinen mittaaminen perustuu yksilöiden lopputulemien ja olosuhteiden väliseen yhteyteen. Kulloinkin tarkasteltava ryhmä voidaan jakaa tyyppeihin olosuhteita kuvaavilla indikaattoreilla. Empiirisen tarkastelun taustalla on oletettu kausaalinen malli, jossa lopputulemien yhteys yksilön kontrollin ulkopuolella oleviin olosuhdetekijöihin tulkitaan näistä olosuhdetekijöistä johtuvaksi. Tyyppien väliset erot lopputulemissa tulkitaan olosuhteiden vaikutukseksi ja siten mahdollisuuksien eriarvoisuudeksi.

Epäsuora lähestymistapa huomioi sen, että ympäristö vaikuttaa lopputulemiin myös vaikuttamalla yksilöiden kannustimiin. Yksilön voi olla järkevää olla käyttämättä merkittäviä resursseja koulutukseen, jos pitkä opintie näyttää saavuttamattomalta. Siltä osin kuin panostusten erot johtuvat ympäristön kannustimista, niistä syntyviä lopputulemaerojakin on pidettävä ympäristötekijöistä johtuvina.

\section{LAHJAKKUUS, RAKENTEELLINEN ERIARVOISUUS JA PARHAIDEN VALTA}

Asetelma mutkistuu, jos yksilö on itse vastuussa omasta lahjakkuudestaan. Vaikka lahjakkuuttaan ei voi valita, synnynnäiseen lahjakkuuteen perustuvia eroja oppimistuloksissa ei useinkaan pidetä lähtökohtaisesti epäoikeudenmukaisina.

Synnynnäisen lahjakkuuden huomioiminen ei ole ongelma mahdollisuuksien tasa-arvon mittaamisen yleiselle strategialle niin kauan kuin kyse on vain yksilöiden välisistä eroista. Ongelmaksi se muodostuu, jos sosioekonomisesti määrittyneet yhteiskuntaryhmät, perustuivatpa ne jäsentensä sukupuoleen, etniseen taustaan tai vanhempien koulutustasoon, eroavat systemaattisesti toisistaan.

Koulutuspolitiikka kohtaa tällöin yhteiskuntafilosofisen keskustelun peruskysymyksen: päätyvätkö eri ympäristöistä tulevat ihmiset eri lopputulemiin ympäristöerojen takia vai koska ihmiset eri ympäristöissä ovat sisäsyntyisesti erilaisia (ks. Kalenius 2020, luvut 5-7)? Jos eroja selitetään ympäristöllä, suotuisammissa oloissa kasvaneet, esimerkiksi ylempien sosioekonomisten ryhmien lapset, saavat oloistaan etua, joka vaikuttaa heidän lopputulemiinsa. Vaihtoehtoisen käsityksen mukaan olojen ja lopputulosten suhde johtuu siitä, että joidenkin lasten vanhemmat ovat sisäsyntyisesti lahjakkaampia tai ahkerampia. Tällöin lapset perivät lahjakkuuden ja saavat hyvät olot, mutta heidän lopputulemansa seuraavat peritystä lahjakkuudesta, eivät suotuisammista kasvuoloista.

Se, johtuvatko lopputuloserot synnynnäisistä eroista vai ympäristöstä, on yhteiskuntapoliittisen keskustelun ytimessä, koska se vaikuttaa ratkaisevas- 
J OHTUVATKO

\section{LOPPUTULOSEROT}

\section{SYNNYNNÄISIST Ä EROISTA}

\author{
VAI YMP ̈̈RISTÖST $\ddot{A}$, ON \\ YHTEISKUNTAPOLIITTISEN
}

KESKUSTELUN YDINKYSYMYS.

ti siihen, millaisia koulutus- ja yhteiskuntapoliittisia vaihtoehtoja on tarjolla. Jos erot selittyvät ympäristöeroilla, ryhmien välisiä eroja voidaan kaventaa parantamalla heikossa asemassa olevien tuloksia ja samalla saavuttaa parempi osaamisen taso. Synnynnäisistä syistä johtuvien erojen kaventaminen taas johtaa tulosten huononemiseen, kun kaventaminen saavutetaan lahjakkaampien tasapäistämisellä.

Empiirisen tutkimuskirjallisuuden perusteella ei toistaiseksi voida arvioida, missä määrin taustaan liittyvät erot eri ryhmien kognitiivisissa tulemissa, kuten älykkyydessä tai oppimistuloksissa, selittyvät ryhmien sisäsyntyisillä eroilla. Käytettävissä oleva käyttäytymisgeneettinen tutkimus ei sovellu sen arvioimiseen, missä määrin ryhmien välisiä eroja voitaisiin kaventaa esimerkiksi koulutuspoliittisilla toimilla.

Empiirisessä analyysissani lähestyin kysymystä lopputulemien taustasta epäsuorasti tarkastellessani mahdollisuuksien tasa-arvon ja oppimistulosten tason välistä suhdetta järjestelmätason vertailussa. Aikuisten osaamistutkimuksen tulokset osoittavat, että mahdollisuuksien tasa-arvon ja oppimistulosten taso ovat järjestelmätasolla positiivisessa yhteydessä myös korkeimmasta sosioekonomisesta taustasta tulevilla: mitä paremmin mahdollisuuksien tasa-arvo maassa toteutuu, sitä korkeamman osaamisen tason eri väestöryhmät saavuttavat. Yhteys on sitä voimakkaampi, mitä pidempi on tarkastelun aikaväli.

Koulutusmahdollisuuksien tasa-arvo ja tulojen eriarvoisuus myös ennustavat oppimistulosten tason vaihtelua yli ajan ja syntymäkohorttien. Tämä viittaa siihen, että ryhmien väliset erot johtuvat IALS- ja PIAAC-tutkimusten kattamissa kehittyneissäkin maissa yhä merkittävässä määrin ympä- ristötekijöistä. Tällöin koulutuspolitiikassa voidaan yhä tavoitella yhtäaikaisesti oppimistulosten ja tasaarvon parantamista sen sijaan, että tarvitsisi pelätä tasa-arvon johtavan tasapäistämiseen ja tulosten huononemiseen.

Tutkimustulokseni tukevat PISA-tutkimuksen vahvistamaa käsitystä: tasa-arvo ja oppimistulosten taso eivät ole vaihtosuhteessa keskenään vaan muodostavat pikemminkin toisiaan vahvistavan hyvän kehän.

\section{KOULUTUSREFORMIT JA AIKUISTEN OSAAMINEN}

Tarkastelin väitöksessäni myös, onko aikuisten osaamistutkimusten aineistossa löydettävissä merkkejä koulutuspoliittisista uudistuksista. Jotta kohorttien väliset erot olisi mahdollista kytkeä koulutuspoliittisiin muutoksiin, niiden tulisi pysyä varsin vakaina aikuisuudessa. Jos erot muuttuvat jatkuvasti koko aikuisuuden ajan, niitä ei voida liittää kohorttien erilaisiin nuoruuden koulutuskokemuksiin.

Mitatun mahdollisuuksien tasa-arvon vakautta aikuisuudessa voidaan arvioida sekä IALS- että PIAAC-tutkimuksiin osallistuneissa maissa, koska niissä sama kohortti voidaan havaita sekä 1990-luvulla (IALS) että 2010-luvulla (PIAAC). Mittausten välisestä pitkästä ajasta huolimatta molemmat tutkimukset antavat yhdenmukaisen kuvan mahdollisuuksien tasa-arvosta kussakin kohortissa, sekä kohorttien välisistä eroista, vaikka kohorttikohtaiset otokset ovat kooltaan vaatimattomia. Tämä pätee pääosin niissäkin ikäryhmissä, jotka olivat 16-19-vuotiaita IALS-tutkimuksessa, mikä viittaa siihen, että järjestelmätasolla taustaan liittyvät osaamisen erot vakiintuvat viimeistään aikuistumisvaiheessa.

Aikuisaineistossa muutaman tuhannen aikuisen otos kattaa 16-65-vuotiaan väestön. Yksittäisen syntymäkohortin otos jää siten pieneksi, ja mahdollisuudet verrata yksittäistä uudistusta edeltäviä kohortteja sitä seuranneisiin kohortteihin ovat rajallisia. Mahdollisuuksien tasa-arvo kuitenkin toteutuu pääosin paremmin niissä kohorteissa, jotka ovat käyneet koulunsa oppivelvollisuuden pidennysten ja koulutusjärjestelmän yhtenäisyyttä kehittävien uudistusten jälkeen kuin uudistuksia edeltävissä kohorteissa. 
Suomen aikuisaineistoa koskevat tulokseni sopivat aiempaan tutkimustietoon oppimistulosten ja koulutuksellisen tasa-arvon kehittymisestä aina 1930-luvulla syntyneistä kohorteista alkaen.

Kansainvälisten nuorten oppimistulostutkimusten perusteella on havaittavissa, että Suomessa korkeasti ja matalasti koulutetusta taustasta tulevien väliset erot kaventuvat tultaessa 1950-luvulta syntyneistä kohorteista myöhemmin syntyneisiin. Ero kääntyy kasvuun 1990-luvun alussa syntyneistä kohorteista alkaen. (Salmela-Aro \& Chmielewski 2019.) Tulokseni aikuisten oppimistulosaineistosta kertovat pitkälti saman tarinan: ensin taustaa koskevat oppimistuloserot pienenevät, mutta kääntyvät sitten kasvuun. Käännöksen ajoitus kuitenkin eroaa. Aikuisaineistossa kehityssuunnan muutos sijoittuu 1970ja 1980-lukujen vaihteessa syntyneisiin kohortteihin.

Sama aikuis- ja nuorisoaineistojen perusteella tehtävä ajoitusero on aiemmin ollut havaittavissa oppimistulosten tasoa koskevissa tutkimuksissa. Nuorten oppimistulosten perusteella laadituissa kokooma-aikasarjoissa oppimistulosten paraneminen Suomessa kääntyi huononemiseksi vuodesta 2000 tai 2006 alkaen (Hanushek \& Woessmann 2015, Altinok, Diebolt \& Demeulemeester 2014), eli vuosina 1985 tai 1991 syntyneiden kohorttien jälkeen. Koulutuksen arviointineuvoston (Karvi) kansallisten matematiikan arviointien perusteella laadittu aikasarja sijoittaa käänteen vuoteen 2000, eli vuonna 1984 syntyneisiin.

Aikuisaineistojen perusteella osaamistason huippu saavutettiin aiemmin kuin nuorisoaineistoissa. Vuoden 1998 IALS-tutkimuksessa parhaat tulokset sai 20-24-vuotiaiden, eli 1970-luvun puolivälissä syntyneiden, ikäryhmä. Vuoden 2012 PIAAC-tutkimuksessa osaamisen taso oli paras 30-34-vuotiailla, eli 1970- ja 1980-lukujen vaihteessa syntyneillä. Puolustusvoimien kognitiivisia kykyjä mittaavaan P1- kokeeseen perustuva pitkittäisaikasarja antaa pitkälti saman ajoituksen kuin IALS- ja PIAACtutkimusten poikkileikkaustiedot. Sen mukaan matemaattisen ja kielellisen päättelyn osaaminen ovat heikenneet 1970-luvun jälkipuolella syntyneistä kohorteista lähtien (Economic Policy Council 2018).
Ajoituserosta huolimatta sekä nuorten että aikuisten oppimistulosaineistot osoittavat, että oppimistulosten taso ja mahdollisuuksien tasa-arvo ovat Suomessa kehittyneet toistensa peilikuvina. Mahdollisuuksien tasa-arvo näyttää Suomessa olleen yhteydessä suomalaisten saavuttamaan kansainvälisesti korkeaan oppimistulosten tasoon.

\section{PISA-MENESTYKSEN SYYT}

Kehityskulun käänteiden ajoitus on kiinnostava Suomen PISA-menestyksen syistä käydyn keskustelun kannalta. Menestystä on selitetty tasa-arvon lisäksi maisteritasoisella opettajankoulutuksella sekä koulujen ja opettajien laajalla autonomialla. Menestystä 2000-luvun ensimmäisissä PISA-tutkimuksissa on verrattu menestykseen aiemmissa kansainvälisissä oppimistulosvertailuissa, ja erojen on tulkittu kertovan 1990-luvulla tehdyistä valinnoista (Sahlberg 2011). Tulkintaa ei voi ongelmattomasti sovittaa nuorten oppimistuloksia koskevaan tutkimusnäyttöön, mutta vielä huonommin se sopii aikuisaineistojen antamiin tuloksiin olennaisten muutosten ajoittumisesta.

Koulujen paikallista autonomiaa kasvattivat voimakkaasti 1990-luvulla erityisesti kaksi koulutuspoliittista uudistusta: opetussuunnitelman perusteiden uudistuminen vuonna 1994 ja koulutuslainsäädännön uudistuminen vuoden 1999 alusta. Ne lisäsivät paikallisen opetussuunnitelman itsenäisyyttä, toivat mahdollisuuksia opetuksen eriyttämiseen niin sanotun painotetun opetuksen ryhmissä ja tekivät koulutusta säätelevästä lainsäädännöstä korostetusti puitelainsäädäntöä, jonka sisällä koulu voidaan käytännössä järjestää vapaasti.

On esitetty, että ennen 1990-luvun uudistuksia opettaja näyttäytyi koulutuspoliittisessa kontekstissa haasteena ja uudistusten esteenä. Opettajan pitkäaikainen de facto -autonomia luokkahuoneessa ei näyttäytynyt vahvuutena ja voimavarana vaan järjestelmää koskevana ongelmana, joka rajoitti koulutuspoliittisen päätöksenteon mahdollisuuksia vaikuttaa koulun käytäntöihin. (Simola 2014).

Tulosten paranemisen ja heikkenemisen aikajana sopii osin huonosti yleisiin käsityksiin PISA-menes- 
MAHDOLLISUUKSIEN TASA-

ARVO ON SuOMESSA OLLUT

\section{YHTEYDESSÄ SUOMALAISTEN}

\section{SAAVUTTAMAAN}

KANSAINV ÄLISESTI HYVIIN

OPPIMISTULOKSIIN.

tyksen syistä. Sekä nuorten että aikuisten oppimistulosvertailujen perusteella tunnetuimmat selitykset ovat ajoituksellisesti ongelmallisia.

Kasvatustieteellisten tutkimuslaitosten yhteistyöjärjestönä perustettu International Association for the Evaluation of Educational Achievement (IEA) toteutti vuonna 1991 kansainvälisen lukutaitotutkimuksen (Reading Literacy Study), jossa suomalaiset sekä neljäs- että yhdeksäsluokkalaiset olivat vertailumaiden parhaita. Vaikka suomalaisnuorten lukutaito oli vuoden 2000 PISA-vertailussa paras, tulos ei siten kertonut tilanteen muuttuneen 1990-luvulla. PISA vain herätti paljon enemmän huomiota kuin 1990-luvun alun menestys.

Suuri ero aiempaan menestykseen sen sijaan oli matematiikassa, jossa Suomen menestys oli vuoden 1981 SIMS-tutkimuksessa varsin vaatimaton ja vuoden 2000 PISA-tutkimuksessa erinomainen. Ongelma on, että PISA mittaa matematiikkaa IALS-tutkimuksesta tuodulla lähestymistavalla, matemaattista lukutaitoa painottaen. 1980-luvun opetussuunnitelmapohjaisesti matematiikan osaamista arvioineiden vertailujen kanssa vertailukelpoinen tutkimus on Trends in International Mathematics and Science Study (TIMSS), joka on jatkoa vuoden 1981 SIMS-tutkimukselle. Vuoden 1999 TIMSS-R-tutkimuksessa suomalaisnuorten matematiikan osaaminen taas ei ollut kansainvälisessä kärjessä vaan lähellä keskitasoa (Mullis ym. 2000). Oppimistulosten voimakas paraneminen 1990-luvulla näyttääkin virhetulkinnalta. Illuusio noususta syntyy, kun hyvää menestystä yhdellä mittaustavalla verrataan aiempaan vertailuun eri mittaustavalla - mutta ero on enemmän mittarissa kuin suorittajassa.
Tulkintaa, että oppimistulokset eivät 1990-luvulla parantuneet merkittävästi, vahvistavat kokooma-aikasarjat oppimistulosten kehittymisestä nuorten osaamistutkimuksissa. Hanushekin ja Woessmannin (2015) aikasarjassa tulokset kääntyvät laskuun vuoden 2006 huippuvuoden jälkeen, Altinokin, Dieboltin ja Demeulemeesterin (2014) aikasarjassa taas jo vuoden 2000 jälkeen. Molemmissa oppimistulokset nousevat vain vähän vuoden 1995 jälkeen. Aikuisaineistoissa oppimistulosten ja tasa-arvon koheneminen hidastuu ja kääntyy laskuun vieläkin aiemmin, korkeimman osaamisen ja mahdollisuuksien tasa-arvon toteutuessa jo 1990-luvun puolivälissä peruskoulunsa päättäneissä kohorteissa.

\section{0-LUKU JA SUOMALAISEN KOULUN KEHITYS}

Aikuisaineistossa näkyvä mahdollisuuksien tasaarvon voimakas heikkeneminen 1990-luvulla viittaa siihen, että Suomessa on yhä vakavammin syytä arvioida uudelleen 1990-luvun koulutuspoliittisten uudistusten merkitystä koulun nykytilalle.

Opettajien koulutuksella tuloksia on ongelmallista selittää siksi, että maisterikoulutetut opettajat yleistyivät opettajakunnassa liian myöhään suhteessa oppimistulosten paranemiseen ja koulun tasa-arvoistumiseen. Ensimmäiset maisteritasoisen opettajankoulutuksen opiskelijat aloittivat vuonna 1979, ja tavoiteaikataulussa opiskelleet valmistuivat vuonna 1984. Siten 1990-luvun puoliväliin mennessä maisterikoulutettujen opettajien osuus peruskoulun opettajista nousi arviolta noin neljännekseen ja ylitti puolet vasta 2000-luvun alkuvuosina. Maisteritason koulutus ei aikajanalla helposti asetukaan huipputulosten selittääksi, jos valtaosa parannuksista saavutettiin ennen vuotta 1995, kuten nuorisoaineisto kertoo, tai jos tulokset kääntyivät laskuun 1990-luvun puolivälissä, mihin aikuisaineisto viittaa.

Vastaavasti autonomian kyky selittää oppimistuloksia tai tasa-arvoa on aikajanan valossa ongelmallinen. Autonomia lisääntyi ennen kaikkea 1990-luvun puolivälissä ja sen jälkeen, samanaikaisesti tai vain vähän ennen kuin osaaminen ja mahdollisuuksien tasa-arvo kääntyivät laskuun. 
OSAAMISPERUSTEISUUS ON

JUURTUNUT AMMATILLISESTA

OSAAMISESTA JA JATKUVASTA

OPPIMISESTA K ̈̈YTYYN

KESKUSTELUUN VARSIN

KAPEASSA MUODOSSA.

1990-luvun koulutuspoliittisten ratkaisujen arviointia vaikeuttavat samanaikaiset laajat yhteiskunnalliset muutokset, kun yhteiskunnallinen eriarvoisuus, kuten tuloerot, lisääntyivät. Väitöstutkimukseni perusteella tuloerot ovat negatiivisessa tilastollisessa yhteydessä mahdollisuuksien tasa-arvon toteutumisen kanssa. Lisäksi mahdollisuuksien tasa-arvo ja tuloerot 1990-luvun IALS-tutkimuksen toteuttamisen aikaan näyttävät ennustavan varsin hyvin osaamisen tasoa 2010-luvun PIAAC-tutkimuksessa.

Suomessa ja muissa Pohjoismaissa näkyvä mahdollisuuksien tasa-arvon heikkeneminen 1990-luvulla ei välttämättä johdukaan koulutuspolitiikan muutoksista vaan esimerkiksi tuloerojen voimakkaasta kasvusta. Tulkintaa tukee se havainto, että mahdollisuuksien tasa-arvo heikkenee useissa Itä-Euroopan maissa, joissa tuloerot kasvoivat 1990-luvulla huomattavasti.

Toisaalta aiempi tutkimus tukee sitä mahdollisuutta, että koulutuspoliittiset ratkaisut ovat voineet vaikuttaa 2000-luvulla havaittuun koulutuksellisen eriarvoisuuden lisääntymiseen ja oppimistulosten heikkenemiseen. 1990-luvun uudistuksissa vapautettiin vanhempien mahdollisuutta valita lapsensa koulu. Kouluvalinnan yhtenä moottorina ovat toimineet niin sanotut painotetun opetuksen ryhmät, joiden kautta tasoryhmien, jopa rinnakkaiskoulujärjestelmän elementtien, on nähty palanneen peruskouluun (Seppänen, Rinne \& Sairanen 2012). Lisääntyneen kouluvalinnan on myös todettu heikentäneen tasaarvon toteutumista (Kuosmanen 2020). Havainto on kiinnostava, koska eräiden aiempien tutkimusten (Woessmann 2009) perusteella koulutusjärjestelmän sisäinen eriytyminen heikentää sekä tasa-arvoa että oppimistuloksia. Ei olisikaan täysin yllättävää, jos koulun sisäistä eriytymistä vahvistavat uudistukset johtaisivat eriarvoisuuden lisääntymiseen ja tulosten heikkenemiseen. Samaan yhteyteen viittaa Suomessa se, että oppimistulokset ovat heikenneet eniten matalan osaamisen tai matalan sosiaalisen taustan ryhmissä ja vähiten korkeimmasta sosioekonomisesta taustasta tulevien tai parhaat oppimistulokset saavuttavien ryhmissä.

Keskustelua koulujärjestelmän eriytymisestä on Suomessa vaikeuttanut se, että koulutus on eriytynyt koulujen sisällä, kun muissa Pohjoismaissa on lisääntynyt koulujen välinen eriytyminen. PISA-tutkimuksessa koulujen väliset erot Suomessa näyttävät erityisen pieniltä siksi, että monessa PISA-maassa 15 -vuotiaat ovat jo useaan opintosuuntaukseen eriytyneessä järjestelmässä, mutta Suomessa vielä yhtenäiskoulun piirissä. Kun aineisto mahdollistaa luokkatason tarkastelun, luokkien väliset erot ovat kasvaneet voimakkaasti, ja Suomi erottuu muista Pohjoismaista, joissa oppilasryhmien eriytyminen on toteutunut suurelta osin koulujen eriytymisenä (Yang Hansen, Gustafsson \& Rosén 2014). Havainto tekee ymmärrettäväksi sen, miksi sosioekonomiset oppimistuloserot ovat Suomessa kasvaneet, mutta koulujen väliset erot ovat pysyneet esimerkiksi PISA-tutkimuksessa pieninä.

\section{AIKUISKOULUTUS JA OSAAMINEN}

Taustaan liittyvien erojen vakaus aikuisuudessa herättää kysymyksiä aikuiskoulutuksen ja jatkuvan oppimisen tulevaisuudesta. Oppiminen aikuisiässä ei ole riittänyt muuttamaan osaamisjakaumaa ratkaisevasti, vaan nuoruusiässä näkyvät erot säilyvät aikuisuudessa.

PIAAC-tutkimuksen perusteella on todettu, että noin 600000 suomalaisella aikuisella on vaikeuksia suorittaa yksinkertaisia laskutoimituksia tai ymmärtää suoraviivaistakaan tekstiä (OECD 2013). Taloudellisen yhteistyön ja kehityksen järjestö OECD (2020) kiinnitti jatkuvan oppimisen selvityksessään huomiota tarpeeseen ryhtyä erityisiin toimiin, jotta koulutusjärjestelmä voisi muun muassa hakevalla toiminnalla tavoittaa ne aikuiset, joilla on heikot perustaidot. 
Tässä suhteessa on kiinnostavaa, että osaamisperusteisuus näyttää juurtuneen ammatillisesta osaamisesta ja jatkuvasta oppimisesta käytyyn keskusteluun varsin kapeassa muodossa. Osaamisperusteisuudessa osaaminen ymmärretään pitkälti käytännön työelämän tilanteissa, yksittäisessä työsuorituksessa osoitettavissa oleviksi tiedoiksi ja taidoiksi. Vähemmälle huomiolle jää vaikeammin yksittäisessä työsuoritteessa osoitettava laaja-alainen osaaminen, kuten luku- ja laskutaito sekä oppimaan oppiminen, joiden varassa on työuran aikainen jatkuva oppiminen.

Kun osaaminen ymmärretään kapeasti työsuorituskohtaisesti, koulutuksessa painottuvat kulloinkin tarvittavat erityistaidot ja tarve reagoida koulutuksella nopeasti työelämän muuttuviin tarpeisiin. Yksittäisiin työtehtäviin kiinnittyvä osaamispuhe rakentuu paradoksaalisesti ajatukselle, että koulutus tuottaa erityisosaamista, jota työelämä kuluttaa, kunnes työntekijällä on tarve palata koulutukseen saadakseen itselleen lisää osaamista.

Toinen tapa ymmärtää koulutusjärjestelmän rooli nopeasti muuttuvaa työelämää palvelevan osaamisen tuottamisessa on ollut ajatella, että olennaista on kouluttaa työvoimaa, joka kykenee itse kehittämään omaa osaamistaan. Tällöin työ ei kuluta osaamista, vaan on keskeinen osaamisen tuottamisen tapa.

Ammatillisesta koulutuksesta puhuttaessa me yhä tunnistamme työelämässä tapahtuvan oppimisen merkityksen. Jatkuvan oppimisen osalta keskustellaan kuitenkin vain vähän siitä, millä tavoin työtehtävät, työpaikat ja työyhteisöt tulisi järjestää, jotta tuettaisiin osaamisen jatkuvaa kehittymistä, syventymistä, laajentumista ja uudelleensuuntautumista työelämän muuttuvien tarpeiden mukaan.

Mikä tehtävä yrityksillä on yhä vahvemmin osaamisen kehittymistä tukevaan työelämään pääsemisessä? Miten valtiovalta voi tukea ja kannustaa yrityksiä vahvistamaan työntekijöiden osaamista työssä eikä vain työhön liittyvässä kouluttautumisessa? Miten työuran alkuvaiheen koulutusta pitää kehittää, jotta se sallii työntekijälle oman ammatillisen osaamisen jatkuvan syventämisen ja laajentamisen työssä, ilman että on tarvetta palata formaaliin koulutukseen?

\section{KOULUTUSPOLITIIKKA EILEN JA HUOMENNA}

Suomen parhaan PISA-menestyksen päivinä 2000-luvun alussa kunniaa riitti kaikille - niin peruskoululle kuin sitä merkittävästi muuttaneille 1990-luvun koulutuspoliittisille uudistuksille. Tarinat menestyksen syistä ovat muodostuneet osaksi suomalaista koulutuspoliittista itseymmärrystä, vaikka niiden tueksi oleva tutkimusnäyttö on usein ohut tai olematon.

On helppo todeta, että kaiken taustalla on kasvoton kulttuurimuutos, jonka tarkka luonne ja syyt ovat tuntemattomia. Ansio menestyksestä kuuluu tällöin erinomaisille opettajille, kouluille ja politiikalle, mutta ongelmat vain ilmaantuvat. Sekä koululle että yhteiskunnalle olisi tervetullutta yhä paremmin tiedostaa, että ymmärryksemme niin menestyksen kuin sen hiipumisen syistä on vakavasti puutteellista. Selityksiä on paljon - me vain emme tiedä, mitkä niistä ovat oikeita.

Jatkuvan oppimisen käsitteen alla uudelleen käytävä keskustelu oppimisesta aikuisuudessa pakottaa ajattelemaan yhä tarkemmin perustaitojen ja erityisen ammattiosaamisen suhdetta koulutuksessa. Koulutammeko työuraa vai työsuoritusta varten? Onko ammattiosaaminen ensisijaisesti joukko erityistaitoja, joita voi osoittaa yksittäisissä työsuorituksissa vai yleistä ammattisivistystä, joka mahdollistaa ammatillisen osaamisen jatkuvan kehittymisen ja syventymisen? Molemmat vaihtoehdot vaativat uudistuvaa jatkuvaa oppimista ja aikuiskoulutusta, mutta muutosten suunta on erilainen.

Kapeasti rajatun osaamiskäsityksen korostuminen koulutuspoliittisessa keskustelussa viittaa siihen, että keskustelu siitä, missä määrin vahvat perustaidot ja laaja-alainen sivistys ovat keskeisiä tavoitteita koko aikuisväestölle - ja kuuluvat kaikille - jatkunee vielä pitkälle 2000-luvulle.

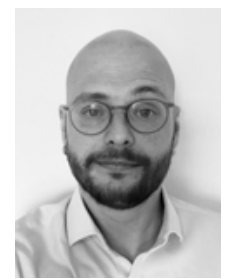

ALEKSI KALENIUS

FT, VTM, erityisasiantuntija SOSTE Suomen sosiaali ja terveys ry

(D) https://orcid.org/0000-00018866-0086 
1 Tarkemmin oppimismahdollisuuksien tasa-arvon teoreettisemmista ulottuvuuksista kts. Kalenius 2020, luvut $1-5$.

\section{LÄHTEET}

Altinok, N., Diebolt, C. \& Demeulemeester, J. L. (2014). A new international database on education quality: 1965-2010. Applied Economics 46(11), 1212-1247.

Binkley, M., \& Williams, T. (1996). Reading Literacy in the United States. Findings from the IEA Reading Literacy Study. US Government Printing Office, Superintendent of Documents, Washington, DC.

Economic Policy Council (2018). Economic Policy Council Report 2017. VATT Institute for Economic Research.

Hanushek, E. A. \& Woessmann, L. (2015). The Knowledge Capital of Nations: Education and the Economics of Growth. MIT press.

Kalenius, A. (2020) Are We There Yet? - Equality of learning opportunity in theory and practice. Helsinki Studies in Education, number 78.

Kuosmanen, I. (2020). Essays on Economics of Immigration and Education. Publication series of the Helsinki Center of Economic Research.

Mullis, I. V., Martin, M. O., Gonzalez, E. J., \& International Association for the Evaluation of Educational Achievement (2000). TIMSS 1999: international mathematics report: findings from IEA's repeat of the Third International Mathematics and Science Study at the eighth grade. International Study Center.

Musset, P. (2015). Building Skills for All: a review of Finland. Policy Insights from the Survey of Adult Skills. OECD Skills Studies. OECD Publishing.

Sahlberg, P. (2011). Finnish Lessons: What can the world learn from educational change in Finland? New York: Teachers College Press.
Salmela-Aro, K., \& Chmielewski, A. K. (2019). Socioeconomic Inequality and Student Outcomes in Finnish Schools. In Socioeconomic Inequality and Student Outcomes. Singapore: Springer, 153-168.

Seppänen, P., Rinne, R., \& Sairanen, V. (2012). Suomalaisen yhtenäiskoulun eriytyvät koulutiet: oppilasvalikointi perusopetuksessa, esimerkkinä Turun koulumarkkinat. Yhteiskuntapolitiikka 77(1), 16-33.

Simola, H. (2014). The Finnish Education Mystery: Historical and sociological essays on schooling in Finland. London: Routledge.

OECD (2013). Skills Outlook 2013. First Results from the Survey of Adult Skills. OECD Publishing.

OECD (2016). PISA 2015 Results (Volume I): Excellence and Equity in Education. PISA. OECD Publishing.

OECD (2020), Continuous Learning in Working Life in Finland, Getting Skills Right. OECD Publishing.

Unesco (1953). Progress of literacy in various countries: A preliminary statistical study of available census data since 1900. Paris: Unesco.

Woessmann, L. (2009). International evidence on school tracking: A review. CESifo DICE Report (1), 26-34.

Yang Hansen, K., Gustafsson, J. E. \& Rosén, M. (2014). School performance differences and policy variations in Finland, Norway and Sweden. Northern lights on TIMSS and PIRLS. Nordic Council of Ministers, 25-48. 